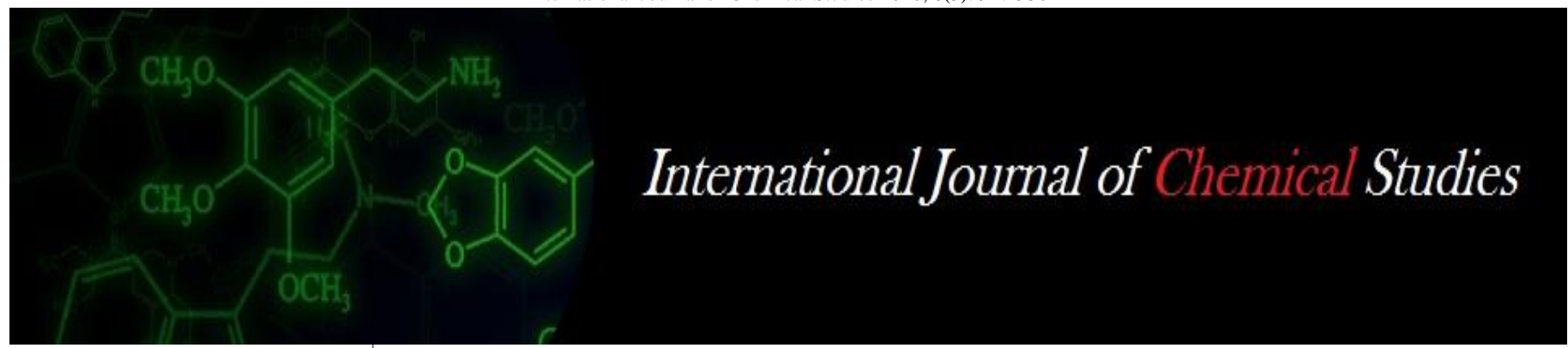

P-ISSN: 2349-8528

E-ISSN: 2321-4902

www.chemijournal.com

IJCS 2020; 8(5): 927-930

(C) 2020 IJCS

Received: 12-06-2020

Accepted: 16-08-2020

\section{MS Kadam}

College of Horticulture, Dapoli,

Ratnagiri, Maharashtra, India

\section{KV Malshe}

College of Horticulture, Dapoli,

Ratnagiri, Maharashtra, India

\section{BR Salvi}

College of Horticulture, Dapoli,

Ratnagiri, Maharashtra, India

\section{SS Chavan}

College of Horticulture, Dapoli, Ratnagiri, Maharashtra, India
Corresponding Author: MS Kadam

College of Horticulture, Dapoli, Ratnagiri, Maharashtra, India

\section{Effect of plant growth regulators on flowering and flower yield in gaillardia (Gaiilardia pulchella) cv. Local double}

\author{
MS Kadam, KV Malshe, BR Salvi and SS Chavan
}

DOI: https://doi.org/10.22271/chemi.2020.v8.i5m.10417

\begin{abstract}
The experiment was conducted at Experimental farm of College of Horticulture, Dapoli, Dr. Balasaheb Sawant Konkan Krishi Vidyapeeth, Dapoli, Dist. Ratnagiri during Rabi season of the year 2019-20 to assess the effect of plant growth regulators on flowering and flower yield in gaillardia. The experiment was laid out in Randomized Block Design (RBD) with three replications with nine plant growth regulator treatments viz; T1 NAA@100 ppm, T2- NAA@200 ppm, T3- GA $@ 100$ ppm, T4- GA 30200 ppm, T5- CCC@ 1500 ppm, T6- CCC @ 3000 ppm, T7- PBZ @ 250 ppm, T8- PBZ @ 500 ppm and T9Control. The early initiation of flowering (62.00 DAT) was observed in GA3 @ 200 ppm treatment. The delayed initiation of flowering (90.33 DAT) and was in PBZ @ 500 ppm. The significantly minimum number of days required for 50\% flowering (69.67 days) and longest flowering duration (130.73 days) were also taken in $\mathrm{GA}_{3} @ 200$ ppm treatment. The lowest number of days required to flower opening from bud stage (4.33 days) and highest flower yield per plant (213.99 gm) were in GA3 @ 100 ppm $\left(\mathrm{T}_{3}\right)$.
\end{abstract}

Keywords: Gaillardia, plant growth regulators, $\mathrm{GA}_{3}$, flowering, yield

\section{Introduction}

Gaillardia belongs to Asteraceae family, native of South-Western United State and Mexico. It is popularly known as "Blanket Flower". The common name may refer to the resemblance of inflorescence to the brightly patterned blankets made by Native Americans, or to the ability of wild texa blanket the ground with colonies. There are about 12 species, out of which Gaillardia pulchella Fouge, and Gaillardia cristata are of horticultural importance (Bose and Yadav, 1989) ${ }^{[1]}$.

It is one of the most popular flower in India because of its easy cultivation, wide adaptability to varying soils and climatic conditions with long duration of flowering and attractive flower colours. It is mostly grown for its profuse flowers and some are used for making garlands, for religious ceremony, for making flower beds and as herbaceous flower borders. It's gorgeously coloured flowers are best arranged in copper bowls or simple plain-coloured vases.

The successful commercial cultivation of the crop depends on several factors like, genetic, environment and management factors. In recent years, scientists have given due attention to the idea of regulating plant growth, yield and quality with the application of plant growth regulators in various ways. Plant growth regulators (PGRs) are used for controlling many aspects of plant growth and development, including height, flower initiation, and fruit set. Several PGRs interrupt physiological pathways of hormones and enzymes, which disrupts normal growth (Danielson, 2005) ${ }^{[2]}$, which ultimately affect the plant growth, yield and quality of flowers and yield.

As gaillardia is impending crop in Konkan region of Maharashtra on commercial scale, it is necessary to develop the package of practices suited for the region. The alteration of growth and promotion of flowering by using plant growth regulators is a task and view this view the present investigation was undertaken to assess the effect of plant growth regulators on flowering and flower yield in gaillardia. 


\section{Material and Methods}

The experiment was conducted at Experimental farm of College of Horticulture, Dapoli, Dr. Balasaheb Sawant Konkan Krishi Vidyapeeth, Dapoli, Dist. Ratnagiri during Rabi season of the year 2019-20. The experiment was laid out in Randomized Block Design (RBD) with three replications with nine plant growth regulator treatments viz; T1- NAA @ 100 ppm, T2- NAA @ 200 ppm, T3- GA 3 @ 100 ppm, T4$\mathrm{GA}_{3} @ 200$ ppm, T $5^{-} \mathrm{CCC} @ 1500$ ppm, T $6^{-} \mathrm{CCC} @ 3000$ ppm, T $7^{-}$PBZ @ 250 ppm, $\mathrm{T}_{8^{-}}$PBZ @ 00 ppm and $\mathrm{T}_{9^{-}}$ Control. The flat beds of $2.7 \mathrm{~m} \mathrm{X} 1.8 \mathrm{~m}$ were prepared and 30 days old seedlings of gaillardia were transplanted at spacing of $45 \times 45 \mathrm{~cm}$. The recommended cultural practices (Manuring, irrigation, weeding and plant protection, etc.) were followed uniformly to experimental plots. The Spraying with different growth regulators was done thrice i.e. 30, 45 and 60 days after transplanting. The observations on flowering attributes and yield were recorded on randlomly selected five plants. Statistical analysis of the data was carried out by standard method of analysis of variance as given by Panse and Sukhatme (1995) ${ }^{[3]}$.

\section{Results and Discussion}

The data on days required for initiation of flowering after transplanting was presented in Table 1 The data revealed that the significantly early initiation of flowering (62.00 DAT) was observed in treatment $\mathrm{T}_{4}\left(\mathrm{GA}_{3} @ 200 \mathrm{ppm}\right)$. This treatment was at par with the treatment $\mathrm{T}_{3}\left(\mathrm{GA}_{3} @ 100 \mathrm{ppm}\right)$ 64.00 DAT. It was followed by $\mathrm{T}_{7}$ (PBZ @ 250 ppm) 83.67 days, $\mathrm{T}_{5}$ (CCC@1500 ppm) 81.33 days, T 6 (CCC @ 3000 ppm) 79.67 days, T2 (NAA @ 200 ppm) 75.33 days, T 9 (Control) 74.67 days, T1 (NAA @ 100 ppm) 71.33 days. The delayed initiation of flowering (90.33 DAT) was observed in $\mathrm{T}_{8}$ (PBZ @ 500 ppm).

Earliest bud initiation and flowering was observed with the application of $\mathrm{GA}_{3}$ might be due to gibberellins which reduces juvenile period and with the termination of juvenile phase, the shoot apical meristem instead of producing leaves and branches start producing buds. The earliness in flowering of gaillardia by $\mathrm{GA}_{3}$ treatments might be due to increased photosynthetic area and respiration which enhanced $\mathrm{CO}_{2}$ fixation in plants that are associated with early flowering. These results are in close accordance with the Poshiya et al. (1995) ${ }^{[4]}$, Patel (1998) ${ }^{[5]}$, Makwana (1999) ${ }^{[6]}$, and Ghadage et al. (2013) ${ }^{[7]}$ in gaillardia. Result of slight less number of days required for initiation of flowering over control due to NAA treatments were in line with the Poshiya et al. (1995) ${ }^{[4]}$ and Patel (1998) ${ }^{[5]}$ and Patil et al. (2002) ${ }^{[8]}$ in gaillardia.

The data regarding days required for $50 \%$ flowering in gaillardia crop is presented in Table 1. From the data, it is cleared that the significantly minimum number of days required for $50 \%$ flowering (69.67 days) were taken in $\mathrm{T}_{4}$ $\left(\mathrm{GA}_{3} @ 200 \mathrm{ppm}\right)$ and was at par with the treatment $\mathrm{T}_{3}\left(\mathrm{GA}_{3}\right.$ @ 100 ppm) 72.67 days. It was followed by $\mathrm{T}_{5}$ (CCC @ 1500 ppm) 96.33 days, $\mathrm{T}_{7}$ (PBZ @ 250 ppm) 93.67 days, T 6 (CCC @ 3000 ppm) 89.67 days, T 2 (NAA @ 200 ppm) 87.67 days, $\mathrm{T}_{9}$ (Control) 84.33 days, $\mathrm{T}_{1}$ (NAA @ 100 ppm) 81.67 days. The maximum number of days taken for $50 \%$ flowering (98.33 days) was in the treatment $\mathrm{T}_{8}$ (PBZ @ 500 ppm).

Early $50 \%$ flowering was found in the plants treated with $\mathrm{GA}_{3}$ treatment as compared to control and other treatments. It might be due to early production of florigin in $\mathrm{GA}_{3}$ treated plants, as $\mathrm{GA}_{3}$ is component of florigin which is required for the formation of flowers in the plant system (Dabas et al. 2001) ${ }^{[9]}$. These results are in close accordance with the Nagarjuna et al. (1988) ${ }^{[10]}$ in chrysanthemum and Girisha et al. (2013) in daisy.

The data on the effect of plant growth regulators on days to flower opening from bud stage revealed that the period of flower opening also differed significantly and the minimum number of days required to flower opening from bud stage (4.33 days) was recorded in $\mathrm{T}_{3}\left(\mathrm{GA}_{3} @ 100 \mathrm{ppm}\right)$ which was at par with the treatment $\mathrm{T}_{2}$ (NAA @ 200 ppm) 6.33 days and $\mathrm{T}_{4}\left(\mathrm{GA}_{3} @ 200 \mathrm{ppm}\right)$ i.e. 5.33 days (Table 1). It was followed by the treatments $\mathrm{T}_{6}\left(\mathrm{CCC} @ 3000\right.$ ppm) 8.00 days, $\mathrm{T}_{8}$ (PBZ @ 500 ppm) 7.67 days, T 1 (NAA @ 100 ppm) 7.00 days, T $_{6}$ (CCC @ 3000 ppm) 7.00days, T (Control) 7.00 days. However, the maximum number of days to flower opening from bud stage was observed in $\mathrm{T}_{5}$ (CCC @ 1500 ppm) 8.67 days.

Less number of days required for flower bud opening in $\mathrm{GA}_{3}$ might be due to more rapid cell development and elongation. Whereas, growth retardants required more number of days for flower bud opening and the similar results were obtained by Moon et al. (2018) ${ }^{[12]}$ were application of CCC resulted in maximum number of days required to opening of flower from bud initiation in gaillardia.

The data presented in Table 2 revealed that the application of plant growth regulators did not show the significant effect on number of pickings. It was in the range of 8.67 to 12 pickings. Higher number of pickings in control treatment is due to more influence of natural parameters on the untreated plants.

The data on flowering duration as influenced by the PGR treatments are presented in the Table 2. The significantly longest flowering duration (130.73 days) was observed in the treatment $\mathrm{T}_{4}\left(\mathrm{GA}_{3} @ 200 \mathrm{ppm}\right)$ which was statistically at par with the treatment $\mathrm{T}_{3}\left(\mathrm{GA}_{3} @ 100 \mathrm{ppm}\right)$ having period of flowering duration (128.13 days). The shortest flowering duration (102.40 days) was observed in the treatment $\mathrm{T}_{8}$ (PBZ @ 500 ppm).

Gibberellic acid spray recorded a significant longest flowering duration. Advanced bud formation and onset of flowering in $\mathrm{GA}_{3}$ treated plants was attributed to enhanced flowering duration (Dutta et al., 1993) ${ }^{[13]}$. Prolonged flowering duration owing to $\mathrm{GA}_{3}$ was also documented by Dahiya and Rana (2001) ${ }^{[14]}$ in chrysanthemum. Gibberellic acid had an additive effect on flowering duration due to their early induction of flowering. The lowest flowering duration in CCC and PBZ is mainly due to delayed initiation of flowering and inhibition of GA biosynthesis.

The data on flower yield per plant is presented in Table 2 revealed that flower yield per plant in different PGR treatments showed significant variation. Significantly highest flower yield per plant (213.99 gm) was recorded in the treatment $\mathrm{T}_{3} \mathrm{GA}_{3} @ 100 \mathrm{ppm}$. It was at par with the treatment $\mathrm{T}_{1}$ (NAA@ $100 \mathrm{ppm}$ ), $200.68 \mathrm{gm}$. The lowest flower yield per plant (139.24 gm) was observed in the treatment $\mathrm{T}_{2}$ (NAA (a $200 \mathrm{ppm})$. The most impressive yield of flowers per plant, plot and hectare was recorded with treatment $\mathrm{GA}_{3}$ at 100 ppm. The influence of raising the flower yield was due to increase number of branches which led to increase in the number of flowers. After successful vegetative phase only, the plant could step into reproductive phase with better yield. Similar results were found by Poshiya et al. (1995) [4], Ramdevputra et al. (2009) ${ }^{[15]}$ and Ramesh Kumar et al. $(2010)^{[16]}$ 
Table 1: Effect on plant growth regulators on flowering characters in Gaillardia

\begin{tabular}{|c|c|c|c|c|}
\hline \multicolumn{2}{|c|}{ Treatments } & $\begin{array}{c}\text { Days required for } \\
\text { initiation of flowering* }\end{array}$ & $\begin{array}{c}\text { Days required for 50 } \\
\text { per cent flowering* }\end{array}$ & $\begin{array}{c}\text { Days to flower opening } \\
\text { from bud stage }\end{array}$ \\
\hline $\mathrm{T}_{1}$ & NAA $100 \mathrm{ppm}$ & 71.33 & 81.67 & 7.00 \\
\hline $\mathrm{T}_{2}$ & NAA $200 \mathrm{ppm}$ & 75.33 & 87.67 & 6.33 \\
\hline $\mathrm{T}_{3}$ & $\mathrm{GA}_{3} 100 \mathrm{ppm}$ & 64.00 & 72.67 & 4.33 \\
\hline $\mathrm{T}_{4}$ & $\mathrm{GA}_{3} 200 \mathrm{ppm}$ & 62.00 & 69.67 & 5.33 \\
\hline $\mathrm{T}_{5}$ & CCC $1500 \mathrm{ppm}$ & 81.33 & 96.33 & 8.67 \\
\hline $\mathrm{T}_{6}$ & CCC $3000 \mathrm{ppm}$ & 79.67 & 89.67 & 8.00 \\
\hline $\mathrm{T}_{7}$ & PBZ $250 \mathrm{ppm}$ & 83.67 & 93.67 & 7.00 \\
\hline $\mathrm{T}_{8}$ & PBZ 500 ppm & 90.33 & 98.33 & 7.67 \\
\hline $\mathrm{T}_{9}$ & Control & 74.67 & 84.33 & 7.00 \\
\hline & Range & $62.00-90.33$ & $69.67-98.33$ & $4.33-8.67$ \\
\hline & Mean & 75.81 & 86.00 & 6.81 \\
\hline \multicolumn{2}{c|}{ S. Em. \pm} & 1.47 & 1.56 & 0.73 \\
\hline C. D. at 5\% & 4.40 & 4.69 & 2.18 \\
\hline
\end{tabular}

*DAT: Days after Transplanting

Table 2: Effect on plant growth regulators on number of picking, flowering duration and yield in Gaillardia

\begin{tabular}{|c|c|c|c|c|}
\hline \multicolumn{2}{|c|}{ Treatments } & No. of pickings & Flowering Duration (days) & Yield per plant (g) \\
\hline $\mathrm{T}_{1}$ & NAA $100 \mathrm{ppm}$ & 10.33 & 121.20 & 200.68 \\
\hline $\mathrm{T}_{2}$ & NAA $200 \mathrm{ppm}$ & 9.33 & 117.73 & 139.24 \\
\hline $\mathrm{T}_{3}$ & $\mathrm{GA}_{3} 100 \mathrm{ppm}$ & 10.00 & 128.13 & 213.99 \\
\hline $\mathrm{T}_{4}$ & $\mathrm{GA}_{3} 200 \mathrm{ppm}$ & 9.67 & 130.73 & 183.46 \\
\hline $\mathrm{T}_{5}$ & CCC $1500 \mathrm{ppm}$ & 10.33 & 111.07 & 143.05 \\
\hline $\mathrm{T}_{6}$ & CCC $3000 \mathrm{ppm}$ & 8.67 & 114.07 & 177.95 \\
\hline $\mathrm{T}_{7}$ & PBZ $250 \mathrm{ppm}$ & 10.67 & 109.27 & 187.12 \\
\hline $\mathrm{T}_{8}$ & PBZ 500 ppm & 10.67 & 102.40 & 173.00 \\
\hline $\mathrm{T}_{9}$ & Control & 12.00 & 118.07 & 139.71 \\
\hline & Range & $8.67-12.00$ & $102.40-130.73$ & 178.36 \\
\hline \multicolumn{2}{r|}{ Mean } & 10.19 & 116.96 & 7.39 \\
\hline \multicolumn{2}{r}{ S. Em. \pm} & 0.81 & 1.50 & 22.16 \\
\hline
\end{tabular}

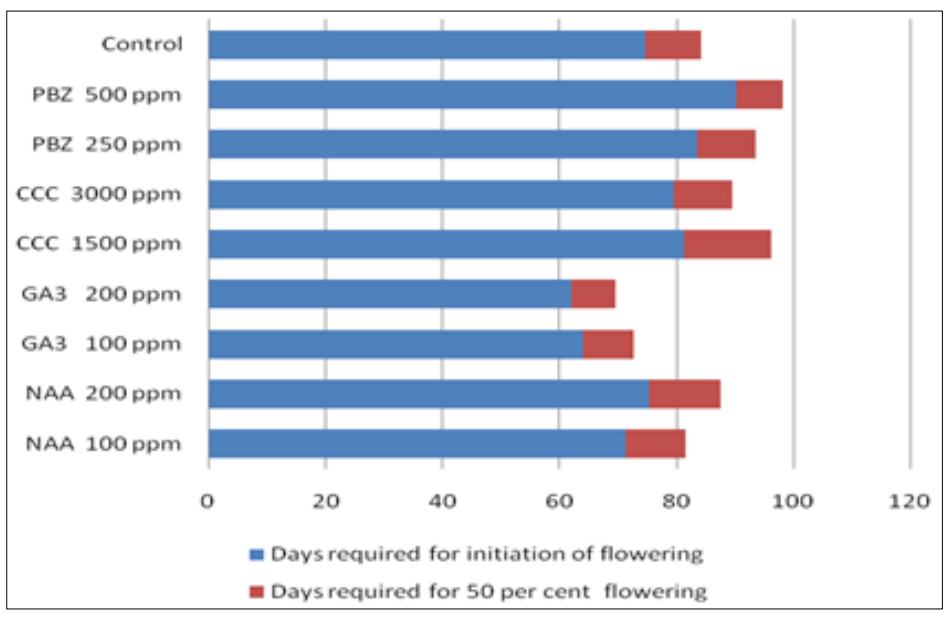

Fig 1: Effect of plant growth regulators on days required for initiation of flowering and for 50\% flowering in gaillardia

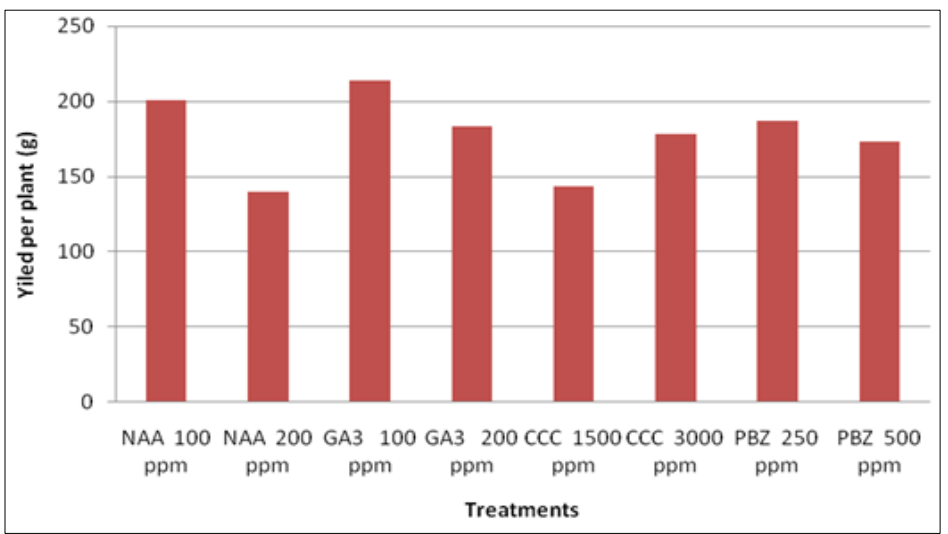

Fig 2: Effect of plant growth regulators on flower yield in gaillardia 


\section{Conclusion}

From the present findings, it is concluded that the gibberellic acid treatments were having profound effect of all the growth and flowering characters of gaillardia. The treatment $\mathrm{T}_{3}$ i.e. $\mathrm{GA}_{3} 100 \mathrm{ppm}$ spray was found best with respect to minimum days required for flower opening from bud stage, number of flowers per plant, flower yield per plant.

\section{References}

1. Bose TK, Yadav LP (Eds). Commercial flowers. Naya prakash, Calcutta, 1989.

2. Danielson HE. Production and performance of gaillardia cultivars and ecotypes. M.Sc. thesis submitted to University of Florida, Florida, USA, 2005.

3. Panse VG, Sukhatme PV. Statistical methods for agricultural workers. ICAR Rev. Ed., 1995, 145-156.

4. Poshiya VK, Katariya GK, Chovatia VP. Effect of rowth substances on growth and yield in gaillardia. J Applied Hort. 1995; 1(1\&2):99-100.

5. Patel SL. Effect of plant growth regulators on growth, flowering and flower yield of annual gaillardia ( $G$. pulchella) var. Lorenziana. M.Sc. (Agri.) thesis submitted to GAU, S.K. Nagar, 1998.

6. Makwana MK. The effect of plant growth regulators on growth, yield and quality of gaillardia (gaillardia pulchella) cv. Lorenziana. M.Sc. (Horti) thesis submitted to Gujarat Agricultural University, Anand Dist. Anand, Gujarat, 1999.

7. Ghadage PU, Raut PD, Golliwar VJ, Thakre SA. Effect of foliar application of different plant growth regulators on growth, yield and quality of gaillardia (var. Yellow Dusty). J Agric. Res. Tec. 2013; 38(1):42-46.

8. Patil AB. Effect of growth regulators on growth, flowering and flower yield of gaillardia. (Gaillardia pulchella Foug.) Cv. Lorenziana. M.Sc. (Agri.) thesis submitted to GAU, S.K. Nagar, 2002.

9. Dabas HK, Mitra L, Dabas S. Effect of different concentrations of GA3, $\mathrm{MH}$ and NAA on primary branches of marigold (Tagetes erecta L.). Indian Agriculturist. 2001; 45(3/4):265-267.

10. Nagarjuna B, Parthasarathy V, Reddy M, Rama M, Reddy NE. Effect of growth regulators and potassium nitrate on growth, flowering and yield of chrysanthemum. South Indian Hort. 1988; 36:136-140.

11. Girisha R, Shirol AM, Kulkarni BS, Reddy BS, Anupa T. Studies on effect of plant growth regulators on growth, flowering and quality of daisy (Aster amellus L.) cv. Dwarf pink. Int. J Agr. Environ. Biotech. 2012; 5(2):127131.

12. Moon SS, Masram GB, Dhepe VR, Gajbhiye RP. Growth and flowering of Gaillardia as influenced by pinching and cycocel. J Soils and Crops. 2018; 28(1):152-156.

13. Dutta JP, Seemanthini Ramdas and Khader. A.M.D. Regulation of flowering by growth regulators in chrysanthemum (Chrysanthemum indicum L.) cv. CO-1. South Ind. Hort. 1993; 41:293-299.

14. Dahiya DS, Rana GS. Regulation of flowering in chrysanthemum as influenced by $\mathrm{GA}_{3}$ and shadehouses of different intensities. South Ind. Hort. 2001; 49:313-314.

15. Ramdevputra MV, Deshmukh HN, Butani AM, Savaliya JJ, Pansuriya AG, Kanzaria DR. Effect of different gibberellic acid $\left(\mathrm{GA}_{3}\right)$ concentrations on growth, flowering and yield of African marigold. Asian J Hort. 2009; 4(1):82-85.
16. Ramesh Kumar, Mohan Ram, Gaur GS. Effect of $\mathrm{GA}_{3}$ and Ethrel on growth and flowering of African marigold cv. Pusa Narangi Gainda. Indian J Hort. 2010; 67(Special Issue):362-366. 